\title{
Rancang Bangun Alarm Deteksi Asap Rokok dan Kebisingan Pada Ruang Kelas Secara Otomatis Berbasis Mikrokontroler
}

\author{
Imas Dian Ratnasari ${ }^{1}$, Dr. H. Noor Hudallah ${ }^{2}$, M.T., Dr. H. M. Harlanu, M.Pd ${ }^{3}$. \\ Jurusan Teknik Elektro, Fakultas Teknik, Universitas Negeri Semarang, Kampus Sekaran, Gunungpati, Semarang, 50229, \\ Indonesia \\ E-mail: imasdian17@gmail.com
}

\begin{abstract}
ABSTRAK
Asap rokok dan kebisingan merupakan masalah yang sering terjadi di sekolah, sedangkan dalam penanganan masalah asap rokok dan kebisingan di sekolah belum maksimal karena belum terdapat alat yang mampu mendeteksi asap rokok sekaligus kebisingan yang diterapkan di sekolah. Pemantauan kondisi ruang kelas agar tetap kondusif perlu diadakan, maka dari itu dilakukan pengembangan alarm deteksi asap rokok dan kebisingan pada ruang kelas secara otomatis. Penelitian ini bertujuan untuk membantu guru dalam memonitoring kondisi di ruang kelas ketika ruang kelas sedang tidak ada guru. Metode penelitian yang digunakan adalah Research and Development $(R \& D)$, yang terdiri dari beberapa tahapan mulai yaitu dari potensi dan masalah, pengumpulan data, desain produk, validasi desain, revisi desain, uji coba produk, revisi produk, ambil data, analisis data, hasil dan pembahasan, simpulan serta selesai. Dalam penelitian dihasilkan alarm deteksi asap rokok dan kebisingan pada ruang kelas secara otomatis berbasis mikrokontroler yang terdiri dari Arduino Uno, sensor TGS 2600, sensor LM 358, Buzzer, LED, LCD dan Fan. Tahap pengujian meliputi uji coba kelayakan. Hasil analisis data dihasilkan persentase sebesar 82,63 dengan kategori valid. Hasil pengujian sensor asap rokok dan kebisingan sudah dikalibrasi sesuai kondisi sebenarnya. Alarm ini, bagian sensor asap rokok tidak dapat diimplementasikan di ruang kelas nyata, sedangkan bagian sensor kebisingan dapat diimplementasikan di ruang kelas nyata dengan menyetting tingkat kepekaan. Saran untuk peneliti selanjutnya, bagian sensor asap rokok dapat dikembangkan, mampu mendeteksi asap rokok pada ruang kelas nyata.
\end{abstract}

Kata kunci: Alarm, Asap, Rokok, Kebisingan.

\section{PENDAHULUAN}

\section{A. Latar Belakang}

Asap rokok merupakan salah satu asap yang mengandung racun berbahaya bagi tubuh. Sedangkan kebisingan merupakan suatu bunyi atau suara yang tidak dikehendaki, zona sekolah memiliki batas maksimum kebisingan yang diperbolehkan yaitu $55 \mathrm{~dB}$ sehingga asap rokok dan kebisingan merupakan kondisi yang dapat mengganggu kesehatan dan kenyamanan seseorang yang berada di dalam ruang kelas. Hal ini dikarenakan hampir setiap orang tidak menyukai adanya asap rokok dan kebisingan dengan berbagai alasan masing-masing orang. Dengan demikian dapat dipahami seseorang akan merasa terganggu dan tidak nyaman di dalam ruangan bila ditemukan asap rokok dan kebisingan.

Adanya siswa yang sedang merokok di dalam ruang kelas sangat meresahkan semua warga sekolah padahal merokok merupakan salah satu larangan yang terdapat di peraturan sekolah, akan tetapi dalam kasus-kasus di sekolah pelanggaran siswa merokok masih sering dijumpai. Siswa yang sedang merokok itu merugikan dirinya sendiri dan seseorang yang berada di sekelilingnya, karena banyak kandungan rokok dan asap rokok yang berbahaya bagi kesehatan tubuh. Kemudian adanya siswa yang sedang membuat gaduh di dalam ruang kelas juga sangat mengganggu kegiatan belajar mengajar di lingkungan sekolah. Menurut peraturan MENKES RI718/MEN.KES/PER/XI/1987 zona sekolah memiliki batas maksimum kebisingan yang diperbolehkan yaitu $55 \mathrm{~dB}$, jadi jika melebihi batas maksimum maka harus ada tindakan seperti peringatan. Oleh sebab itu yang harus dilakukan adalah pemantauan mendeteksi adanya asap rokok dan kebisingan pada suatu ruang kelas maka dari itu penulis akan merancang dan membuat alarm pendeteksi asap rokok dan kebisingan pada ruang kelas secara otomatis berbasis mikrokontroler. Dengan adanya alarm ini mampu meminimalisir 
adanya siswa yang sedang merokok dan membuat gaduh di dalam ruang kelas supaya ruang kelas tetap kondusif.

\section{METODE PENELITIAN}

Pada penelitian ini metode penelitian yang digunakan adalah Research and Development (R\&D), penelitian terdiri dari beberapa tahapan yaitu potensi dan masalah, pengumpulan data, desain produk, validasi desain, revisi desain, uji coba produk, revisi produk, ambil data, analisis data, hasil dan pembahasan, simpulan serta selesai.

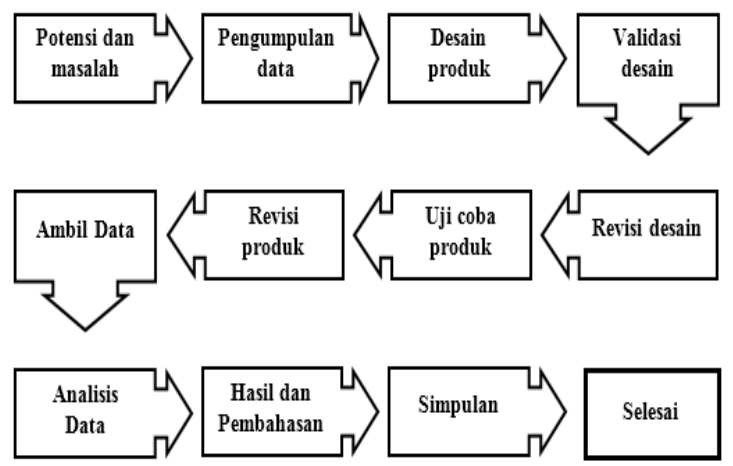

Gambar 1. Desain Penelitian

A. Pembuatan dan Penyempurnaan Alat

Pada penelitian ini pembuatan alat dilakukan dengan merancang komponenkomponen yang diperlukan, membuat desain rangkaian alarm (Gambar 2), desain box alarm, desain box sensor dan membuat program yang yang diharapkan. Setelah alarm dibuat, maka perlu diadakan penyempurnaan pada alarm deteksi asap rokok dan kebisingan.

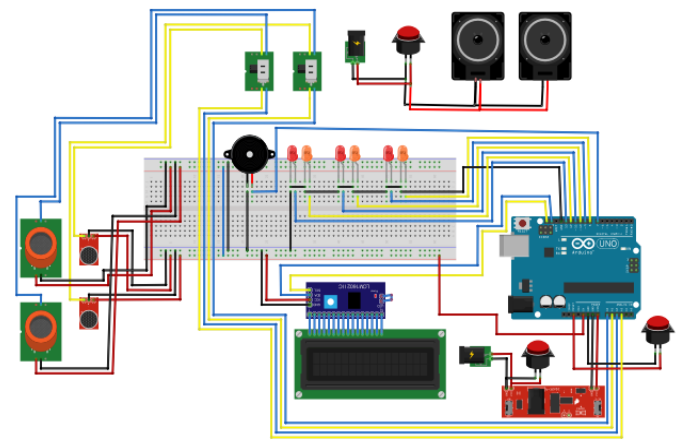

Gambar 2. Desain Rangkaian Alarm Deteksi Asap Rokok dan Kebisingan.
1. Sensor TGS 2600

Sensor jenis TGS 2600 ini merupakan sensor gas karbon monoksida yang berfungsi untuk mengetahui atau mendeteksi konsentrasi gas karbon monoksida yang ada pada kandungan asap rokok. Sensor ini memiliki sensitivitas tinggi dan waktu respon cepat. Keluaran yang dihasilkan oleh sensor ini adalah berupa sinyal analog. Pada sensor ini terdapat nilai resistansi sensor yang dapat berubah bila terkena gas karbon monoksida dan juga sebuah pemanas yang digunakan sebagai pembersihan ruangan sensor dan kontaminasi udara luar. Sensor ini menggunakan catu daya heater 5 Volt DC dan jarak pengukuran dari $1 \mathrm{ppm}-30$ ppm.

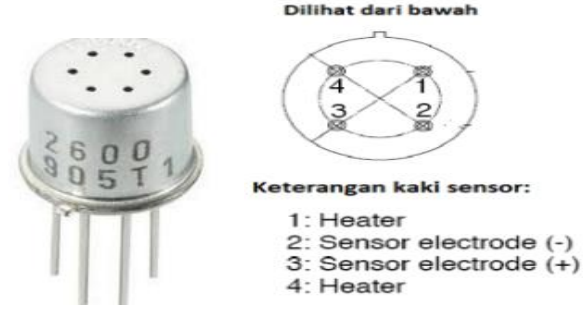

Gambar 3. Sensor TGS 2600

\section{Sensor LM 358}

Sensor LM 358 ini merupakan rangkaian amplifier yang ditambahkan dengan menggunakan mikrofon condeser sebagai masukan, sensitivitas dapat diatur karena sudah tersedia sekrup potensiometer untuk melakukan pengaturan manual output, keluaran yang dihasilkan oleh sensor ini adalah berupa sinyal digital. Sensor ini menggunakan catu daya 3,35 Volt DC.

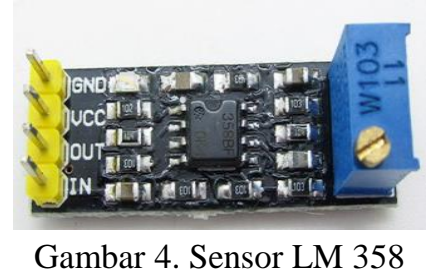

3. Arduino Uno

Arduino adalah board mikrokontroler yang di dalamnya terdapat mikrokontroler, penggunaan jenis mikrokontrolernya berbedabeda tergantung spesifikasinya. Arduino Uno 
menggunakan mikrokontroler berbasis ATmega 328 yang memiliki 14 pin input dan output digital. Dari 6 pin tersebut dapat digunakan sebagai output PWM dan 6 pin lainnya sebagai input analog, $16 \mathrm{MHz}$ osilator kristal, koneksi USB, jack power, ICSP header, dan tombol reset. Board ini menggunakan daya yang terhubung ke komputer dengan kabel USB atau daya eksternal dengan adaptor AC-DC atau baterai. (Syahwil, 2013: 64).

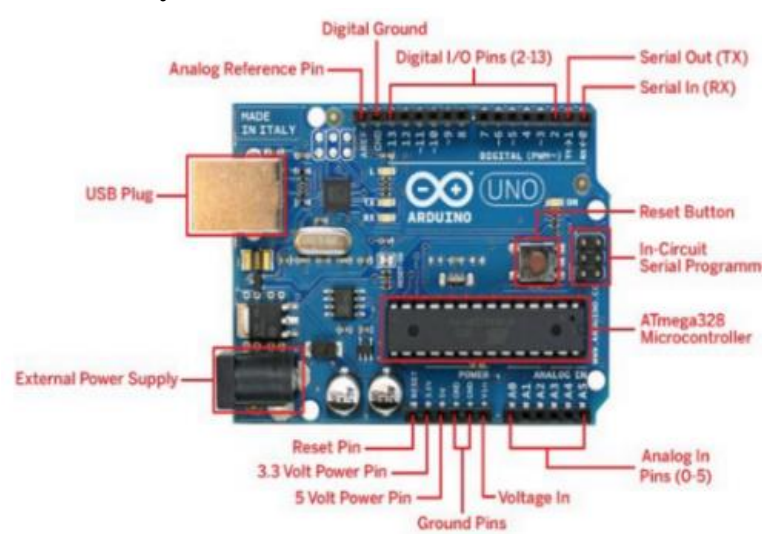

Gambar 5. Arduino Uno

\section{Buzzer}

Buzzer adalah sebuah komponen elektronika yang berfungsi untuk mengubah getaran listrik menjadi getaran suara. Pada Pada dasarnya prinsip kerja buzzer hampir sama dengan loudspeaker, jadi buzzer juga terdiri dari kumparan yang terpasang pada diafragma dan kemudian kumparan tersebut dialiri arus sehingga menjadi elektromagnet. Kumparan tadi akan tertarik ke dalam atau keluar, tergantung dari arah arus dan polaritas magnetnya, karena kumparan dipasang pada diafragma maka setiap getaran kumparan akan menggerakkan diafragma secara bolak-balik sehingga membuat udara bergetar yang akan menghasilkan suara.

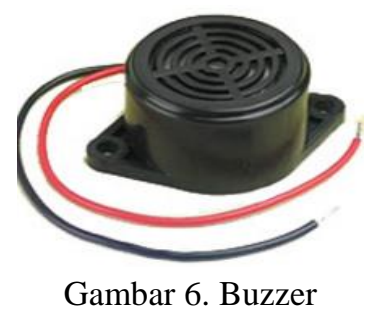

5. LED

LED (Light Emitting Diode) adalah komponen elektronika yang bisa memancarkan cahaya monokromatik ketika diberikan suatu tegangan maju. LED masih termasuk dalam keluarga Dioda. LED terdiri dari sebuah chip dari bahan semikonduktor yang diisi penuh, atau di-dop, dengan ketidakmurnian untuk menciptakan sebuah struktur. Warna cahaya yang dipancarkan LED tergantung dari jenis bahan semikonduktor yang digunakannya.

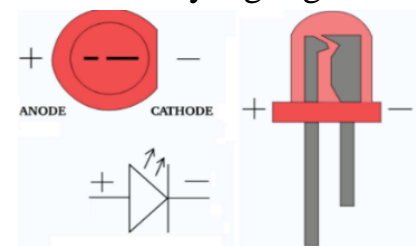

Gambar 7. LED

6. LCD

LCD adalah salah satu komponen elektronika yang berfungsi sebagai tampilan suatu data, baik karakter, huruf ataupun grafik. LCD (Liquid Cristal Display) adalah salah satu jenis display elektronik yang dibuat dengan teknologi CMOS logic yang bekerja dengan tidak menghasilkan cahaya tetapi memantulkan cahaya yang ada di sekelilingnya terhadap front-lit atau mentransmisikan cahaya dari back-lit. LCD (Liquid Cristal Display) berfungsi sebagai penampil data baik dalam bentuk karakter, huruf, angka ataupun grafik. Pada rancang bangun alarm ini peneliti menggunakan LCD 20x4 serta menggunakan tambahan modul I2C, modul ini adalah modul untuk meminimalkan penggunaan pin pada saat menggunakan LCD 20x4. Yang normalnya LCD 20x4 akan membutuhkan sekurangkurangnya 8 pin Arduino Uno dan 1 buah potensiometer untuk dapat diaktifkan, namun dengan LCD tambahan I2C ini hanya perlu menyediakan 2 pin saja. 

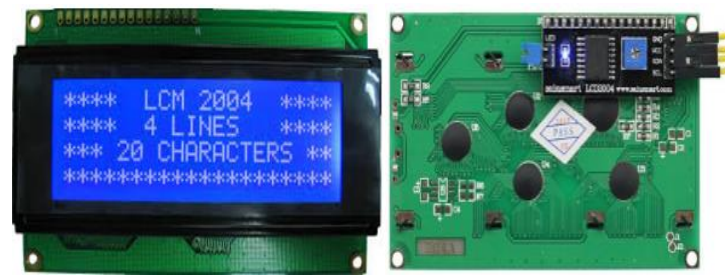

Gambar 8. LCD dengan I2C

\section{Fan}

Fan digunakan sebagai menghisap asap yang berada pada ruang kelas untuk dibuang keluar. Dalam pemasangannya fan dipasang posisi terbalik agar fan dapat menghisap asap di dalam ruangan. Fan adalah sebuah komponen elektronika yang berfungsi menstabilkan udara di dalam ruangan, fan ini dirancang menggunakan baling-baling untuk menarik udara, fan tersebut memaksa sebagian massa asap bergerak ke arah belakang fan, sehingga terciptalah kondisi udara yang dapat menghisap udara di dalam ruang kelas menuju luar ruang kelas.

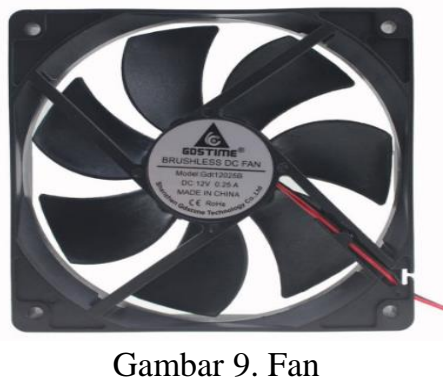

\section{Catu Daya/Power}

Catu daya/power yang digunakan dari komponen dc conveter stepdown dan adaptor. Dc Conveter stepdown adalah komponen yang mamkonversi tegangan dari yang tinggi menjadi rendah dan peneliti mengkonversi tegangan 5 volt dari adaptor menjadi tegangan 3,3 volt untuk mensuplay arduino. Pada dasarnya arduino dapat bekerja di tegangan 5 volt, akan tetapi peneliti menggunakan tegangan 3,5 volt untuk Arduino Uno supaya dapat menghindari ketidakstabilan tegangan. Adaptor adalah sebuah komponen yang dapat menggubah tegangan AC menjadi DC dan adaptor ini digunakan sebagai catu daya/power dari alam.

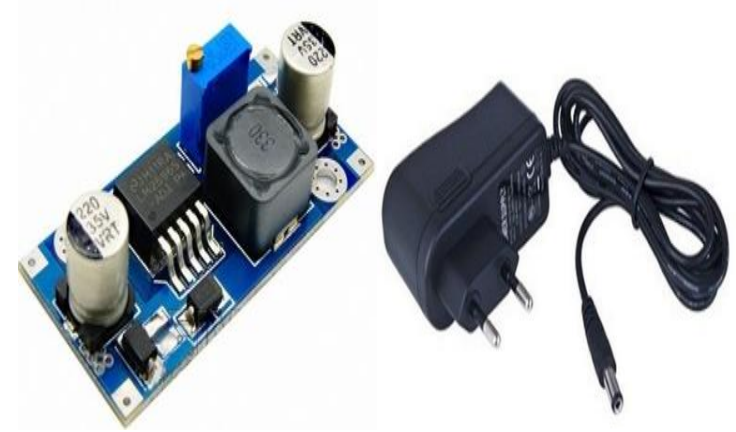

Gambar 10. Catu Daya/Power

A. Validasi Desain

Validasi desain merupakan proses kegiatan untuk menilai apakah rancangan produk sudah sesuai dengan yang dirancang. Validasi produk ini dilakukan dengan menghadirkan pakar atau dosen ahli yang sudah berpengalaman untuk menilai desain tersebut sehingga dapat diketahui kelemahan dan kelebihannya.

\section{B. Uji Keakurasian Alat}

Uji keakurasian ini merupakan kegiatan melakukan pengujian pada tiap-tiap komponen guna mengetahui keakurasiannya. Pengujian keakurasian alat dilakukan dengan cara mengukur tegangan output pada sensor TGS 2600 dan membandingkan hasil nilai $\mathrm{dB}$ pada alarm dengan hasil nilai $\mathrm{dB}$ pada alat sound level meter. Pengujian dilakukan berulang kali dan mencatat data pengukurannya.

\section{Teknik Pengumpulan Data}

Teknik pengumpulan data pada rancang bangun alarm deteksi asap rokok dan kebisingan pada ruang kelas secara otomatis berbasis mikrokontroler dilakukan dengan cara memberi seperangkat pertanyaan atau pernyataan tertulis kepada para ahli untuk dijawab dan melakukan pengujian prototype produk yang diujicobakan dengan memberi asap rokok dan suara di dalam ruangan prototype tersebut. Dalam penelitian ini peneliti menggunakan pengumpulan data berupa angket dengan jenis pertanyaan dan pernyataan tertutup (skala likert) sebagai pengukuran (Sugiyono, 2009: 142). Bentuk angket yang 
digunakan adalah skala bertingkat yaitu sebuah pernyataan diikuti kolom-kolom yang menunjukkan tingkatan-tingkatan, misalnya mulai dari sangat setuju dengan nilai 4 sampai dengan sangat tidak setuju dengan nilai 1 . Angket bergradasi sebaiknya tidak mempunyai pilihan yang ganjil, hal itu dikarenakan biasanya responden akan mencari titik aman dalam menjawab yaitu memilih jawaban yang tengah, sehingga disarankan pilihan jawaban adalah genap (Suharsimi, 2010: 284).

\section{Analisis Data}

Teknik analisis data dilakukan untuk menganalisis hasil pengujian alarm deteksi asap rokok dan kebisingan pada ruang kelas secara otomatis berbasis mikrokontroler, apakah alarm yang dibuat telah sesuai dengan apa yang diharapkan. Pada teknik analisis data, peneliti menggunakan analisis deskriptif kuantitatif, yaitu dengan menganalisis data kuantitatif yang diperoleh dari angket uji ahli melalui uji sampel prototype. Menurut Suharsimi (2010: 286), data kuantitatif yang berwujud angka-angka hasil perhitungan atau pengukuran dapat diproses dengan cara dikali dengan tingkatan nilai kemudian dijumlah, dibandingkan dengan jumlah yang diharapkan dan diperoleh persentase.

\section{HASIL DAN PEMBAHASAN}

\section{Pengujian Sensor TGS 2600}

Pada pengujian sensor TGS 2600, peneliti melakukan pengujian dengan menggunakan sampel asap rokok yang dimasukkan pada prototype ruang kelas. Hasil pengujian ditampilkan pada tabel 1 . Ketika keadaan di dalam prototype ruang kelas tidak ada asap rokok dibutuhkan nilai tegangan kurang dari 3,4 volt dan ketika keadaan di dalam prototype ruang kelas terdapat asap rokok dibutuhkan nilai tegangan lebih dari 3,4 volt maka secara otomatis sistem akan berjalan sesuai yang telah dirancang.
Tabel 1.

Pengujian Sensor TGS 2600

\begin{tabular}{|c|c|c|c|c|c|c|}
\hline Kondisi & $\begin{array}{c}\text { Tegangan } \\
\text { (volt) } \\
\text { seharusnya }\end{array}$ & $\begin{array}{c}\text { Tegangan } \\
\text { (volt) Sensor } \\
\text { Ruang 1 }\end{array}$ & $\begin{array}{c}\text { Tegangan } \\
\text { (volt) Sensor } \\
\text { Ruang 2 }\end{array}$ & $\begin{array}{c}\text { Tampilan } \\
\text { LCD }\end{array}$ & $\begin{array}{c}\text { Led } \\
\text { Merah }\end{array}$ & Buzzer \\
\hline $\begin{array}{c}\text { Tidak ada } \\
\text { asap }\end{array}$ & $<3,4$ & 2,7 & 2,7 & TIDAK ADA & OFF & OFF \\
\hline Ada asap & $>3,4$ & 3,5 & 3,5 & ADA & ON & ON \\
\hline
\end{tabular}

Dari hasil pengujian nilai tegangan sensor TGS 2600 di ruang 1 dan ruang 2 didapatkan perbedaan tegangan yang terukur. Dalam kondisi tidak ada asap rokok tegangan yang terukur adalah 2,7 volt, sedangkan tegangan yang terukur ketika ada asap adalah di atas 3,4 volt. Dari hasil pengukuran inilah alat akan memberikan notifikasi. Secara otomatis ketika tidak ada asap, layar LCD akan menampilkan tulisan "TIDAK ADA" disertai dengan tidak menyalanya LED berwarna merah dan buzzer. Pada hasil pengujian nilai tegangan sensor TGS 2600 ruang 1 dan ruang 2 dalam kondisi ada asap rokok menghasilkan tegangan 3,5 volt dari tegangan yang seharusnya yaitu lebih dari 3,4 volt maka dari itu secara otomatis sistem melakukan penginformasian pada layar LCD berbentuk tulisan "ADA" yang berartikan bahwa sensor mendeteksi adanya asap rokok, kemudian LED berwarna merah dalam kondisi nyala dan buzzer mengeluarkan suara alarm. Peneliti menggunakan nilai tegangan kurang dari 3,4 volt sebagai acuhan ada atau tidaknya adanya asap rokok, karena peneliti telah mengujicobakan ketika tidak ada asap rokok nilai tegangan kurang dari 3,4 volt dan ketika ada asap rokok nilai tegangan lebih dari dari 3,4 volt.

\section{Pengujian Sensor LM 358}

Pada pengujian sensor LM 358 peneliti melakukan pengujian ini dengan memberikan sample suara dengan menempatkan speaker hp (sebagai sumber suara) pada prototype ruang kelas dan menggunakan alat Sound Level Meter sebagai pembanding dari hasil nilai suara pada layar LCD box alarm. 
Tabel 2

Pengujian sensor LM 358

\begin{tabular}{|c|c|c|c|c|c|}
\hline $\begin{array}{c}\text { Pengujian } \\
\text { Ke- }\end{array}$ & $\begin{array}{c}\text { Nilai } \mathrm{dB} \\
\text { Sound Level Meter }\end{array}$ & $\begin{array}{c}\text { Nilai dB } \\
\text { Sensor LM } 358 \\
\text { (ruang 1) }\end{array}$ & Error & $\begin{array}{c}\text { Nilai dB } \\
\text { Sensor LM } 358 \\
\text { (ruang 2) }\end{array}$ & Error \\
\hline 1 & 47,7 & 48,2 & 0,5 & 48,0 & 0,3 \\
\hline 2 & 48,3 & 49,2 & 0,9 & 49,2 & 0,9 \\
\hline 3 & 52,4 & 53,4 & 1 & 53,0 & 0,6 \\
\hline 4 & 47,0 & 48,0 & 1 & 49,1 & 2,1 \\
\hline 5 & 55,5 & 55,3 & 0,2 & 55,3 & 0,2 \\
\hline 6 & 53,7 & 53,5 & 0,2 & 53,7 & 0 \\
\hline 7 & 49,3 & 49,3 & 0 & 50,0 & 0,7 \\
\hline 8 & 54,0 & 54,1 & 0,1 & 54,6 & 0,6 \\
\hline 9 & 57,6 & 58,0 & 0,4 & 57,6 & 0 \\
\hline 10 & 58,0 & 58,0 & 0 & 58,1 & 0,1 \\
\hline \multicolumn{3}{|c|}{ Rata-rata error } & 0,43 & Rata-rata error & 0,55 \\
\hline
\end{tabular}

Dari Tabel 2, didapatkanlah data bahwa dari sepuluh kali pengujian, nilai rata-rata error dari selisih pengukuran di ruangan 1 dengan menggunakan Sound Level Meter dan sensor LM 358 adalah $0,43 \mathrm{~dB}$ dan pengujian di ruangan 2 adalah $0,55 \mathrm{~dB}$.

\section{Pengujian Keseluruhan}

Pada pengujian keseluruhan peneliti melakukan pengujian dengan cara memberikan sample asap rokok dan suara dengan menempatkan sumber suara atau speaker $\mathrm{hp}$ pada prototype ruang 1 dan ruang 2 kemudian mengamati apakah sistem kerja alarm sudah sesuai dengan yang dirancang.

Tabel 3

Pengujian keseluruhan

\begin{tabular}{|c|c|c|c|c|c|c|c|c|c|c|}
\hline \multirow{2}{*}{$\begin{array}{l}\text { Pengujian } \\
\text { Ke- }\end{array}$} & \multicolumn{2}{|c|}{ Ruang 1} & \multicolumn{2}{|c|}{ Ruang 2} & \multicolumn{2}{|c|}{\begin{tabular}{|c|} 
Kondisi Led \\
Ruang 1 \\
\end{tabular}} & \multicolumn{2}{|c|}{$\begin{array}{c}\text { Kondisi Led } \\
\text { Ruang } 2\end{array}$} & \multirow{2}{*}{ Buzzer } & \multirow{2}{*}{$\begin{array}{c}\text { LCD } \\
\text { Menampilkar } \\
\text { Status Asap }\end{array}$} \\
\hline & \begin{tabular}{|c|} 
Asap \\
Rokok \\
\end{tabular} & Bising & $\begin{array}{c}\text { Asap } \\
\text { Rokok }\end{array}$ & Bisin & Merah & Biru & Merah & Biru & & \\
\hline 1 & $x$ & $x$ & $x$ & $x$ & OFF & OFF & OFF & OFF & OFF & $\begin{array}{l}\text { R1 "TIDAK } \\
\text { ADA" } \\
\text { R2 "TIDAK } \\
\text { ADA" }\end{array}$ \\
\hline 2 & $\sqrt{ }$ & $x$ & $x$ & $x$ & ON & OFF & OFF & OFF & ON & $\begin{array}{l}\text { R1 "ADA" } \\
\text { R2 "TIDAK } \\
\text { ADA" }\end{array}$ \\
\hline 3 & $x$ & $\sqrt{ }$ & $x$ & $x$ & OFF & ON & OFF & OFF & ON & $\begin{array}{l}\text { R1 "TIDAK } \\
\text { ADA" } \\
\text { R2 "TIDAK } \\
\text { ADA" }\end{array}$ \\
\hline 4 & $x$ & $x$ & $\sqrt{ }$ & $x$ & OFF & OFF & ON & OFF & ON & $\begin{array}{l}\text { R1 "TIDAK } \\
\text { ADA" } \\
\text { R2 "ADA" }\end{array}$ \\
\hline 5 & $x$ & $x$ & $x$ & $\sqrt{ }$ & OFF & OFF & OFF & ON & ON & $\begin{array}{l}\text { R1 "TIDAK } \\
\text { ADA" } \\
\text { R2 "TIDAK } \\
\text { ADA" }\end{array}$ \\
\hline 6 & $\sqrt{ }$ & $\sqrt{ }$ & $x$ & $x$ & ON & ON & OFF & OFF & ON & $\begin{array}{l}\text { R1 "ADA" } \\
\text { R2 "TIDAK } \\
\text { ADA" }\end{array}$ \\
\hline 7 & $\sqrt{ }$ & $x$ & $\sqrt{ }$ & $x$ & ON & OFF & ON & OFF & ON & $\begin{array}{l}\text { R1 "ADA" } \\
\text { R2 "ADA" }\end{array}$ \\
\hline 8 & $\sqrt{ }$ & $x$ & $x$ & $\sqrt{ }$ & ON & OFF & OFF & ON & ON & $\begin{array}{l}\text { R1 "ADA" } \\
\text { R2 "TIDAK } \\
\text { ADA" }\end{array}$ \\
\hline
\end{tabular}

\begin{tabular}{|c|c|c|c|c|c|c|c|c|c|c|}
\hline 9 & $x$ & $\sqrt{ }$ & $\sqrt{ }$ & $x$ & OFF & $\mathrm{ON}$ & ON & $\mathrm{OFF}$ & $\mathrm{ON}$ & $\begin{array}{l}\text { R1 "TIDAK } \\
\text { ADA" } \\
\text { R2 "ADA" }\end{array}$ \\
\hline 10 & $x$ & $\sqrt{ }$ & $x$ & $\sqrt{ }$ & OFF & $\mathrm{ON}$ & OFF & ON & ON & $\begin{array}{l}\text { R1 "TIDAK } \\
\text { ADA" } \\
\text { R2 "TIDAK } \\
\text { ADA" }\end{array}$ \\
\hline 11 & $x$ & $x$ & $\sqrt{ }$ & $\sqrt{ }$ & OFF & OFF & ON & $\mathrm{ON}$ & $\mathrm{ON}$ & $\begin{array}{l}\text { R1 "TIDAK } \\
\text { ADA" } \\
\text { R2 "ADA" }\end{array}$ \\
\hline 12 & $\sqrt{ }$ & $\sqrt{ }$ & $\sqrt{ }$ & $x$ & ON & $\mathrm{ON}$ & ON & $\mathrm{OFF}$ & ON & $\begin{array}{l}\mathrm{R} 1 \text { "ADA" } \\
\mathrm{R} 2 \text { "ADA" }\end{array}$ \\
\hline 13 & $\sqrt{ }$ & $\sqrt{ }$ & $x$ & $\sqrt{ }$ & ON & $\mathrm{ON}$ & OFF & $\mathrm{ON}$ & $\mathrm{ON}$ & $\begin{array}{l}\text { R1 "ADA" } \\
\text { R2 "TIDAK } \\
\text { ADA" }\end{array}$ \\
\hline 14 & $\sqrt{ }$ & $x$ & $\sqrt{ }$ & $\sqrt{ }$ & $\mathrm{ON}$ & $\mathrm{OFF}$ & ON & $\mathrm{ON}$ & $\mathrm{ON}$ & $\begin{array}{l}\mathrm{R} 1 \text { "ADA" } \\
\mathrm{R} 2 \text { "ADA" }\end{array}$ \\
\hline 15 & $x$ & $\sqrt{ }$ & $\sqrt{ }$ & $\sqrt{ }$ & OFF & ON & ON & $\mathrm{ON}$ & $\mathrm{ON}$ & $\begin{array}{l}\text { R1 "TIDAK } \\
\text { ADA" } \\
\text { R2 "ADA" }\end{array}$ \\
\hline 16 & $\sqrt{ }$ & $\sqrt{ }$ & $\sqrt{ }$ & $\sqrt{ }$ & ON & ON & ON & ON & ON & $\begin{array}{l}R 1 \text { "ADA" } \\
R 2 \text { "ADA" }\end{array}$ \\
\hline
\end{tabular}

Dari data pengujian keseluruhan sistem kerja alarm yang diujicobakan sebanyak 16 kali dengan memberikan asap rokok dan menempatkan sumber suara atau speaker $\mathrm{hp}$ pada prototype ruang 1 dan ruang 2 sudah sesuai dengan rencana.

\section{SIMPULAN DAN SARAN}

A. Simpulan

Berdasarkan hasil penelitian yang dilakukan dapat disimpulkan bahwa:

1. Hasil uji untuk kinerja alarm deteksi asap rokok dan kebisingan menunjukkan seluruh komponen dapat berfungsi secara optimal.

2. Deteksi asap rokok dan kebisingan pada ruang kelas secara otomatis berbasis mikrokontroler ini, bagian sensor asap rokok tidak dapat diimplementasikan di ruang kelas nyata, sedangkan bagian sensor kebisingan dapat diimplementasikan di ruang kelas nyata dengan menyetting tingkat kepekaan.

\section{B. Saran}

Berdasarkan hasil penelitian yang dilakukan, terdapat saran yang diberikan untuk pengembangan lebih lanjut:

1. Pada penelitian selanjutnya, ukuran LCD yang digunakan dapat diperbesar lagi guna mempermudah pengguna untuk membaca notifikasi dari alat. 
2. Alarm deteksi asap rokok ini hanya mampu mendeteksi asap dalam bentuk prototype ruangan, diharapkan peneliti selanjutnya dapat melakukan penelitian pengembangan lagi dengan yang alarm mampu mendeteksi dalam bentuk ruang kelas nyata.

\section{DAFTAR PUSTAKA}

[1] Muhammad Syahwil. 2013. Panduan Mudah Simulasi \& praktek Mikrokontroler Arduino. Yogyakarta: Penerbit Andi.

[2] Sugiyono. 2009. Metode Penelitian Pendidikan Pendekatan Kuantitatif, Kualitatif dan $R \& D$. Bandung: Alfabeta.

[3] Suharsimi Arikunto. 2007. Dasar-Dasar Evaluasi Pendidikan. Jakarta: Bumi Aksara. 